\title{
The Life and Death and Consequences of Canals and Spoil Banks in Salt Marshes
}

\author{
R. Eugene Turner $^{1}$ (D) Erick M. Swenson ${ }^{1}$
}

Received: 19 February 2020 / Accepted: 6 August 2020 / Published online: 7 September 2020

(C) The Author(s) 2020

\begin{abstract}
We describe the consequence and demise of levees (spoil banks) built from dredging canals in Louisiana salt marshes using morphometric measurements made over 30 years, soil collections on the spoil bank and in the salt marshes behind, and complementary observations from other areas. These measurements were used to determine the temporal bounds of how long spoil banks last and if salt marsh soils remaining in salt marshes are affected. If the rates of changes in spoil bank morphology continue, then the estimated life time of the shrub-tree vegetation at a representative spoil bank is 81 years, the spoil bank width is 89 years, and the dredged channel will erode to the center of the spoil bank after 118 years. The soils in marshes behind the spoil bank have a higher bulk density than in reference marshes, accumulate more mineral matter per year, have lower root mass and are weaker. These observations are compatible with measurements of spoil bank width, vegetative cover and soil compaction, and the conversion from wetland to open water on a coastwide scale.
\end{abstract}

Keywords Salt marsh $\cdot$ Soil strength $\cdot$ Waterlogging $\cdot$ Belowground biomass $\cdot$ Land loss $\cdot$ Louisiana

\section{Introduction}

Canals and levees have been built for many reasons for thousands of years and with diverse outcomes. Extensive canal networks existed for irrigation agriculture by 3000 to 2400 B.C. in Mesopotamia and were plagued by salinization (Jacobsen and Adams 1958), wetlands were drained throughout the Roman Empire (Allen and Fulford 1990; Rippon 2000), and extensive farming systems with levees and canals were within Amazonian swamps before European colonization (Mann 2008). In 1599 King Henri IV ordered a national effort to drain wetlands around Poitou, west-central France; colonists from there or nearby came to Nova Scotia, Canada, in the early 1600s, and began converting the Bay of Fundy salt marshes into agriculture (Butzer 2002). Parts of the Fens in England were drained by the Romans, but it was not until the

R. Eugene Turner

euturne@1su.edu

Erick M. Swenson

eswenson@1su.edu

1 Department of Oceanography and Coastal Sciences, Louisiana State University, 1195 Energy Coast and Environment Building, Baton Rouge, Louisiana 70803, USA seventeenth century that it was massively altered when a confluence of Crown support, large landowners, and investors built large canals (Ash 2017). The soils then dewatered and oxidized to subside at up to $10 \mathrm{~cm}_{\text {year }}{ }^{-1}$ in the first few years, and became slower over 100+ years at rates closer to sea level rise (Turner 2004). Eggelsman (1976) showed that these subsidence rates were greater with nutrient availability.

Soil subsidence could be caused by the smallest man-made canals, even if water flow rewets a wetland during tidal cycles. One example is from the $90 \%$ of the pre-colonial tidal wetlands between Maine and Virginia that had mosquito ditches by 1938 (Bourn and Cottam 1950). These ditches were built rather haphazardly, spade-full by spade-full and were usually $0.6 \mathrm{~m}$ wide and $0.6 \mathrm{~m}$ deep with small levees on either side created from the relocated mud. Stearns, Daigh, and colleagues (Daigh et al. 1938; Daigh and Stearns 1939; Stearns et al. 1940) found that one of the principal impacts in a Delaware wetland was to lower the water table and ground level. The ditches were deliberately filled with sediments after muskrats abandoned the marsh. The water level and ground level then rebounded, and muskrats returned within 1 year. These examples and others established some ways that canals and levees change wetland landscapes.

An extensive expansion of much larger canals and levees within wetlands were, and are, being created for mineral 
recovery in Louisiana (Turner and McClenachan 2018) and overseas for the last 100 years (Ohimain 2003). The dredged material is disposed on either side of the canal to form a continuous levee that is a by-product of building the canal. The canal is primarily used to move vessels for drilling and well maintenance, and the levee may become a property boundary or used for a hunting or camp location. The canal is abandoned within months if oil or gas is not found, or abandoned decades later when the mineral lease is no longer profitable. But the spoil bank remains even longer amidst Louisiana's microtidal coastal salt marsh wetlands $(<0.5 \mathrm{~m})$ that are mostly an organic soil. Water cannot normally cross a levee above or belowground, and there are many, many levees, a.k.a., 'spoil banks' . One measure of their abundance is that the 12 southern parishes of Louisiana have a spoil bank length enough to cross the State 80 times from east to west (Turner and McClenachan 2018). The well-documented coastal land loss in Louisiana of $4833 \mathrm{~km}^{2}$ from 1932 to 2016 (Couvillon et al. 2017) rose and fell in temporal synchrony with the rise and fall of canal dredging (and spoil bank construction) and the amount of land loss and canal density is spatially co-distributed across the deltaic plain and with 4.6 ha of additional land lost for each 1 ha of canal (Turner and McClenachan 2018).

It takes only a few months to dredge a canal, but it may be decades before the surface expression of the spoil bank disappears from the salt marsh. Here we describe the demise of one spoil bank using data from biannual measurements over 30 years, and from soil properties along an elevation gradient starting at the water's edge into salt marshes behind the spoil bank. The change in the percent vegetative cover and height of this spoil bank and other spoil banks were compared. These observations were used to determine the temporal bounds of how long spoil banks last and if the soils in the remaining salt marshes are affected.

\section{Materials and Methods}

\section{Site Description}

We studied a canal $3 \mathrm{~km}$ southwest of Cocodrie, LA, located in Terrebonne Parish at $29.224423^{\circ} \mathrm{N},-90.676272^{\circ} \mathrm{W}, 1 \mathrm{~km}$ west of the Houma Navigation Channel (Fig. 1). The Louisiana Department of Natural Resources issued a permit on September 16, 1964 (serial number \#105156). Drilling the exploration hole began 3 months later on December 19, 1964. No oil or gas was produced, and the well was sealed March 9, 1965. Dredging created a canal $925 \mathrm{~m}$ long. The canal width where it began at the waterway was $63 \mathrm{~m}$ wide, the narrowest section was about $21.5 \mathrm{~m}$ wide (at $77 \mathrm{~m}$ from the entrance), and it was originally $74 \mathrm{~m}$ wide at the end (the 'keyhole') where vessels turned around. These canal dimensions are consistent with Monte's (1978) description of a typical canal being dredged to an average $21 \mathrm{~m}$ wide in the main channel and $43 \mathrm{~m}$ in the keyhole, creating a $3.7 \mathrm{~m}$ deep canal that was bordered by a $30.5 \mathrm{~m}$ wide spoil bank on either side.

The dredged material was placed on either side of the created channel to create a continuous 'spoil bank' of dredged material. The soil on the original salt marsh surface became the bottom of the accumulation of dredged materials. The last sediments dredged were at the top of the spoil bank. In this way, a salt marsh adjacent to a canal becomes sandwiched between the mineral layer it covers and the dredged materials placed on top, with the youngest material in between and older material on top. The spoil bank height is nominally $1-3 \mathrm{~m}$ high without the sloughing, erosion or sinking that may occur soon after creation (Nichols 1959). It becomes colonized by trees and shrubs (Monte 1978). A berm is created between the dredge in the canal and the top of the spoil bank as a result of spillage and subsequent sloughing of dredged material down the canal side of the spoil bank. The berm is at too low an elevation to support trees or shrubs and the substrate is composed of silts and clays from the bottom of the canal. It is high enough for salt marsh plants to colonize it. The tree and shrub vegetation on the spoil bank will decline, and the berm expand into the spoil bank as the spoil bank elevation becomes lower.

The spoil banks intersect with natural levees and other spoil banks to create natural barriers that impound salt marshes that may then become open water (Fig. 1a). The spoil bank width is several times wider and higher than in a natural salt marsh (Fig. 1b, d, e) and its weight compresses the organic layer beneath and preserves parts of the original salt marsh surface (Fig. 1c and e).

A natural salt marsh reference site was established $4 \mathrm{~km}$ to the north of the dredged canal we studied, located on the opposite side of the creek where Peterson and Turner (1994) studied aquatic organism migration and emigration at the salt marsh edge. The nearest dredged canal or channel is the Houma Navigation Channel that is $2 \mathrm{~km}$ away from the natural salt marsh. The vegetation at both salt marshes is largely Spartina alterniflora. S. patens and Disticlis spicata are also present, particularly on the slightly higher elevations, but were less than $10 \%$ of the plant cover.

\section{Canal Widening at the Canal Near Cocodrie}

The width of the canal at Cocodrie was estimated using the linear measuring tool and photographs in Google Earth that were dated 1989, 1998, 2004, 2007, 2010, 2015 and 2019. Two other measurements were made on United States Geological Survey 7.5 min topographical maps (Cocodrie Quadrangle) that were based on 1978 and 1990 aerial imagery. The accuracy of measurements for the Google Earth photographs is $1 \mathrm{~m}$ or less (Turner et al. 2016), but some unquantified variability occurs because of changes in water level between photograph dates. 


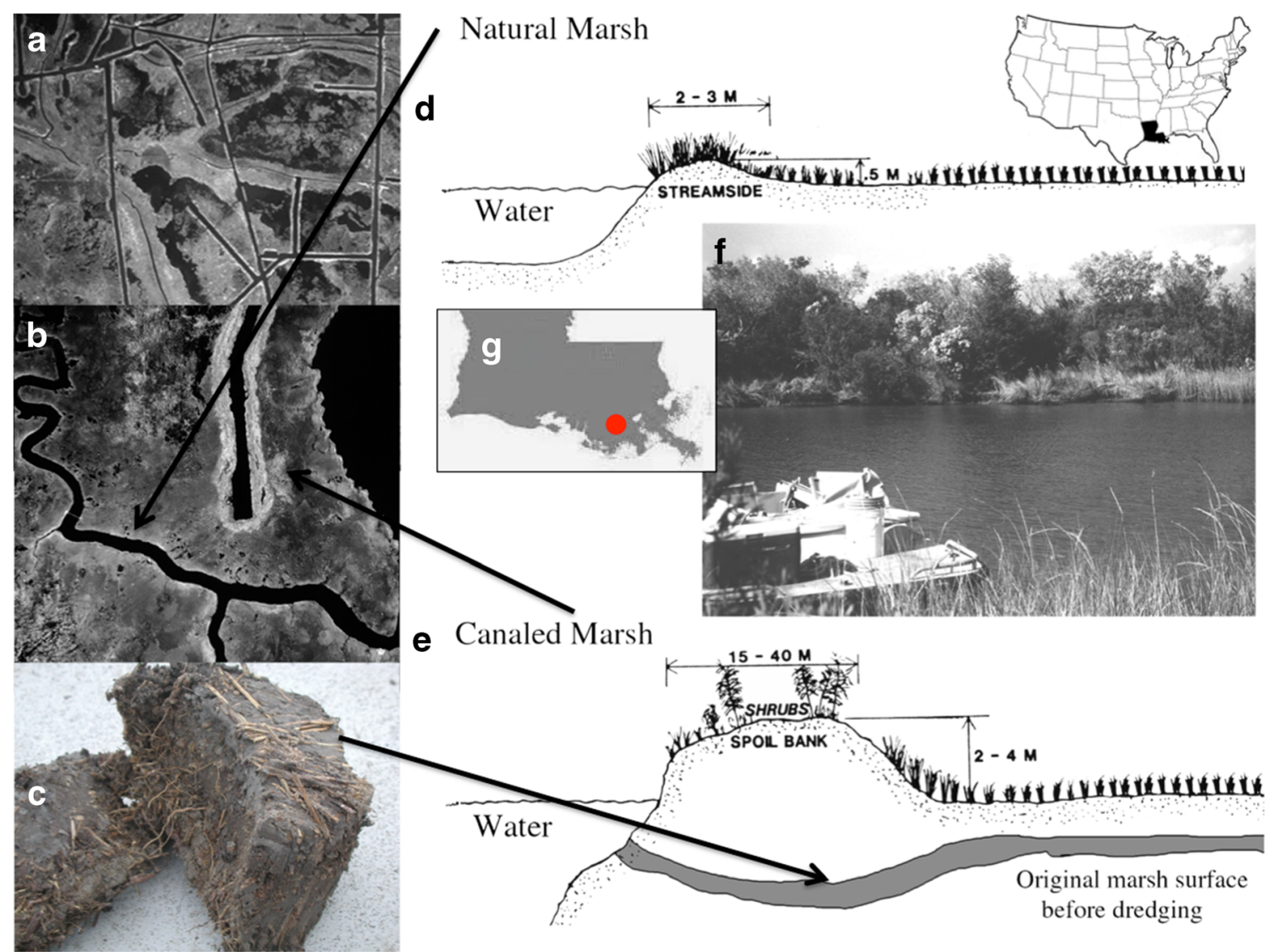

Fig. 1 Spoil banks and canals in two dimensions. a A landscape view of an example of the linear canals and spoil banks intersecting with the distributary levees, impounding marshes that have turned to open water. The aerial image is about $43 \mathrm{~km}$ wide. b A natural drainage channel meandering through the landscape with multiple waterways connecting the marsh and channel. A linear canal is from the top to middle of the aerial imager showing the wider (aka 'keyhole') turning basin and the dredged spoil piled up on either side that is a lighter color. The aerial image is about $925 \mathrm{~m}$ wide. c A soil core recovered from beneath the center of the spoil bank showing the bent over plants from the former

\section{Site Measurements}

Sampling for soil properties was done along the transect from 1990 to 2019 on a biannual basis, and occasionally twice a year. A transect perpendicular to the canal was established and the distance measured from the water's edge to the nearest spoil bank flank, across the spoil bank, and continuing into the salt marsh on the other side. Its maximum length was $50 \mathrm{~m}$ into the salt marsh, but most often its length was $10-20 \mathrm{~m}$. The height of the spoil bank and marsh along the transect was measured using a laser-level transit. The zero elevation (reference baseline) was at the base of the plant on the water-marsh boundary.

A piston corer with a beveled end was used to collect uncompacted $11 \mathrm{~cm}$ long near-surface sediment cores with a volume of $50 \mathrm{~cm}^{-3}$. The corer base was placed on the salt marsh surface in a relatively flat area (avoiding the tops of any clumps), and the core barrel pushed into the salt marsh marsh on the surface of the core. $\mathbf{d}$ A cross-section of a natural marsh. e A cross-section of a marsh with a canal dredged through it and the dredged material placed parallel on one side. The weight of the spoil compresses the original marsh surface and increases subsidence in the sediment layer beneath. The berm has eroded in this example. $\mathbf{f}$ The view from the top of the spoil bank examined from 1990 to 2019 , showing trees and shrubs on the spoil bank on other side of the canal. A berm covered with marsh grass cover is between the spoil bank and the canal. $g$ The general location of the canal studied at $3.6 \mathrm{~km}$ South, southwest @ 22.236 $\mathrm{N}$ and $90.688^{\circ} \mathrm{W}$ (red dot)

substrate using an attached handle. When the proper depth was reached (there was a depth stop on the corer), the barrel was withdrawn from the salt marsh substrate and the cores were extruded into clean, pre-weighed centrifuge tubes. The bulk density cores were returned to the lab where they were cleaned, wiped dry and weighed to the nearest $0.01 \mathrm{~g}$. The caps were removed from the sample tubes and the cores were placed in an oven at $60{ }^{\circ} \mathrm{C}$ until dry. The cores were then removed from the oven, re-capped and re-weighed. The weights were used to calculate the wet and dry bulk densities $\left(\mathrm{g} \mathrm{cm}^{-3}\right)$ along each transect.

Soil strength was measured along the transects using a Dunham E-290 Hand Vane Tester equipped with a $19.5 \times$ 40-mm vane placed at $10-\mathrm{cm}$ intervals between the surface and $100 \mathrm{~cm}$ deep (Turner et al. 2020). The skin friction of a rod without vanes was $<0.1 \mathrm{kPa}$ (kilo Pascal; kPa). Five to six replicate measurements were made at each depth interval within each sampling location. We describe these 
measurements as 'soil shear strength'. All measurements between 20 and $40 \mathrm{~cm}$ were averaged and the standard error calculated $(\mu \pm 1 \mathrm{SE})$. We recognize that there are many other important aspects of soil integrity involving elasticity, anchoring strength, root biomechanics, etc. (Niklas and Spatz 2012).

We used a simple and inexpensive method to measure unconfined soil infiltration in situ that is easily learned. The method employs a $4 \mathrm{~cm}$ wide inside diameter $(4.86 \mathrm{~cm}$ outside diameter) clear plastic tube whose pointed lower end was slowly pushed into the salt marsh to a depth of $1 \mathrm{~m}$. The portion of the tube $21-25 \mathrm{~cm}$ below the salt marsh surface had 24 holes drilled using a \#52 wire size drill bit (0.063 in. diameter). Water was put into the top end $1.5 \mathrm{~m}$ above the salt marsh, allowed to settle and bubbles removed by one or two opening and closings of a hand-operated valve positioned at $0.5 \mathrm{~m}$ above the salt marsh. The open upper end of the tube above the salt marsh was marked at $10 \mathrm{~cm}$ intervals. The tube was filled to $5-10 \mathrm{~cm}$ above the $0 \mathrm{~cm}$ mark, the valve opened, and the rate of water flow out the buried holes timed with a stop watch $\left(\mathrm{cm} \mathrm{s}^{-1}\right)$. A maximum of two measurements were attempted at each location to minimize opportunities to create new paths for water to flow belowground. The unconfined flow in air is $13.3 \mathrm{~cm} \mathrm{~s}^{-1}$ ). There are few water percolation measurements on the spoil bank because flow was almost always negligible.

\section{Statistics}

Linear regressions of the data were calculated using Prism software (Prism 8.4.2 (464) software (C) 2020 GraphPad Software, Inc., La Jolla, CA).

\section{Results}

Two examples of the elevation profile of the spoil bank and natural salt marsh in 1993 and 2006 are in Fig. 2. The spoil bank peak was at least $1 \mathrm{~m}$ higher than the elevation of the

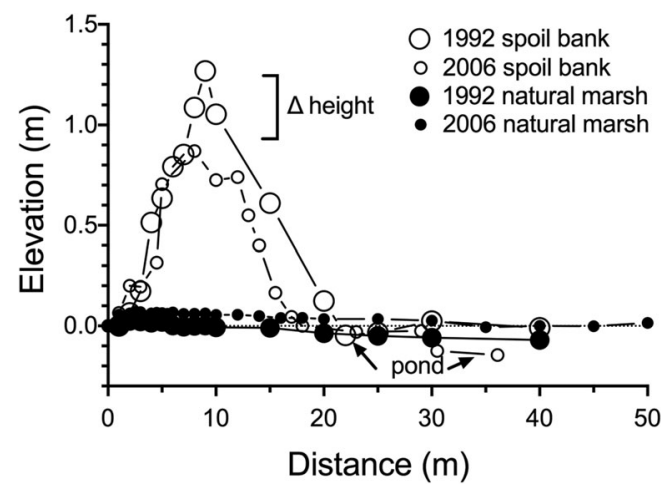

Fig. 2 An elevation profile of the natural marsh and the marsh with the spoil bank in 1993 and 2006 levee in the natural marsh, and dropped $40 \mathrm{~cm}$ by 2006, and was narrower. The salt marsh behind the spoil bank was within $10 \mathrm{~cm}$ of the elevation in the natural salt marsh beyond $30 \mathrm{~m}$, but 10-20 cm lower closer to the spoil bank (Fig. 2). A pond $30 \mathrm{~m}$ from the spoil bank developed on the salt marsh between 1992 and 2006, but was gone after 2006 .

The changes in the dimensions of the spoil bank from 1990 to 2019 are in Fig. 3. The peak height of the spoil bank (Fig. $3 a)$ declined at $1.90 \mathrm{~cm}_{\text {year }}{ }^{-1}$. If it continues at this rate, then it will be at the salt marsh level about 88 years after it was formed. The distance from the canal edge to the spoil bank peak (Fig. 3b) declined at $10.4 \mathrm{~cm}_{\text {year }}{ }^{-1}$. If the widening rate continues, then the canal width will be at the middle of the spoil bank about 118 years after the canal was dredged. The canal width (Fig. 3c) increased at $31 \mathrm{~cm}^{\text {year }}{ }^{-1}$ across the entire canal, or $15 \mathrm{~cm}_{\text {year }}^{-1}$ if widening is equal on both sides. The spoil bank height is declining towards zero (water level) faster than the berm width is narrowing (Fig. 3d).

The changes in spoil bank width measured from the canal edge to the salt marsh behind the spoil bank are compared in Fig. 4 to the width of nine differently aged canals $(1,2,5,10$, 20 and 25 year) for the salt marshes measured by Monte (1978). The spoil bank width declines to zero after 50 years using Monte's data $\left(\mathrm{Y}=-0.673 *\right.$ age $+33.67 ; \mathrm{R}^{2}=0.73, \mathrm{~F}=$ 18.6, $p<0.01, n=9$ ), after 89 years using the data for the Cocodrie canal $\left(\mathrm{Y}=-0.208 *\right.$ age $+24.55 ; \mathrm{R}^{2}=0.61, \mathrm{~F}=$ 15.6, $p<0.01, n=12)$. A linear regression of all data had a zero intercept after 84 years $\left(\mathrm{Y}=-0.36 * \mathrm{X}+30.16\left(\mathrm{R}^{2}=0.72\right.\right.$, $\mathrm{F}=46.8, p<0.01, n=21)$.

The percent remaining shrub and tree coverage on the spoil bank at the Cocodrie spoil bank are in Fig. 5. The equation for the percent spoil bank and age of the canals is $\mathrm{Y}=$ $-0.01574 * \mathrm{X}+1.181\left(p<0.01 ; \mathrm{F}=42.5 ; \mathrm{R}^{2}=0.87\right)$. The zero intercept (no spoil bank remaining) is at 81 years.

The bulk density of the spoil bank and adjoining salt marsh ranged from 0.1 to $1.2 \mathrm{~g} \mathrm{~cm}^{-3}$, but the highest bulk density on the natural levee was $0.5 \mathrm{~g} \mathrm{~cm}^{-3}$ (Fig. 6). The changes in bulk density $\left(\mathrm{g} \mathrm{cm}^{-3}\right)$, shear vane strength $(\mathrm{kPa})$, and percolation rate $\left(\mathrm{cm} \mathrm{s}^{-1}\right)$ along their respective transects are in Fig. 7 . The bulk density was highest in the berm and spoil bank, and the bulk density in the salt marsh behind it was higher than in the natural salt marsh (Fig. 7a). The bulk density of the spoil bank was 3-5 times higher than in the salt marsh $50 \mathrm{~m}$ away.

The shear vane strength at the berm, spoil bank and edge of the spoil bank was higher than all other numbers, but dropped to the lowest value at $10 \mathrm{~m}$ and beyond the spoil bank. The shear vane strength in the natural marsh was lowest at the edge of the natural salt marsh but mostly steady at 10-12 kPa (Fig. $7 b)$. The percolation rates $\left(\mathrm{cm} \mathrm{s}^{-1}\right)$ in the natural salt marsh were lower than in the salt marsh behind the spoil bank, and lowest on top of the spoil bank (Fig. 7c).

The percolation rate $\left(\mathrm{cm} \mathrm{s}^{-1}\right)$ in the $20-40 \mathrm{~cm}$ deep layer was inversely related to the shear vane strength $(\mathrm{kPa})$ in the 
Fig. 3 The changes in spoil bank dimensions from 1990 to 2019. a The height of the peak declined at $1.9 \mathrm{~cm}$ year $^{-1}$. b The distance from the canal edge to the spoil bank peak declined at $10 \mathrm{~cm}$ year $^{-1}$. $\mathbf{c}$ The canal width increased at $31 \mathrm{~cm}$ year $^{-1}$ across the canal, or $15 \mathrm{~cm}$ year $^{-1}$ if equal on both sides. $\mathbf{d}$ The peak height of the spoil bank will be at marsh level sooner than erosion from the canal edge will expand into it
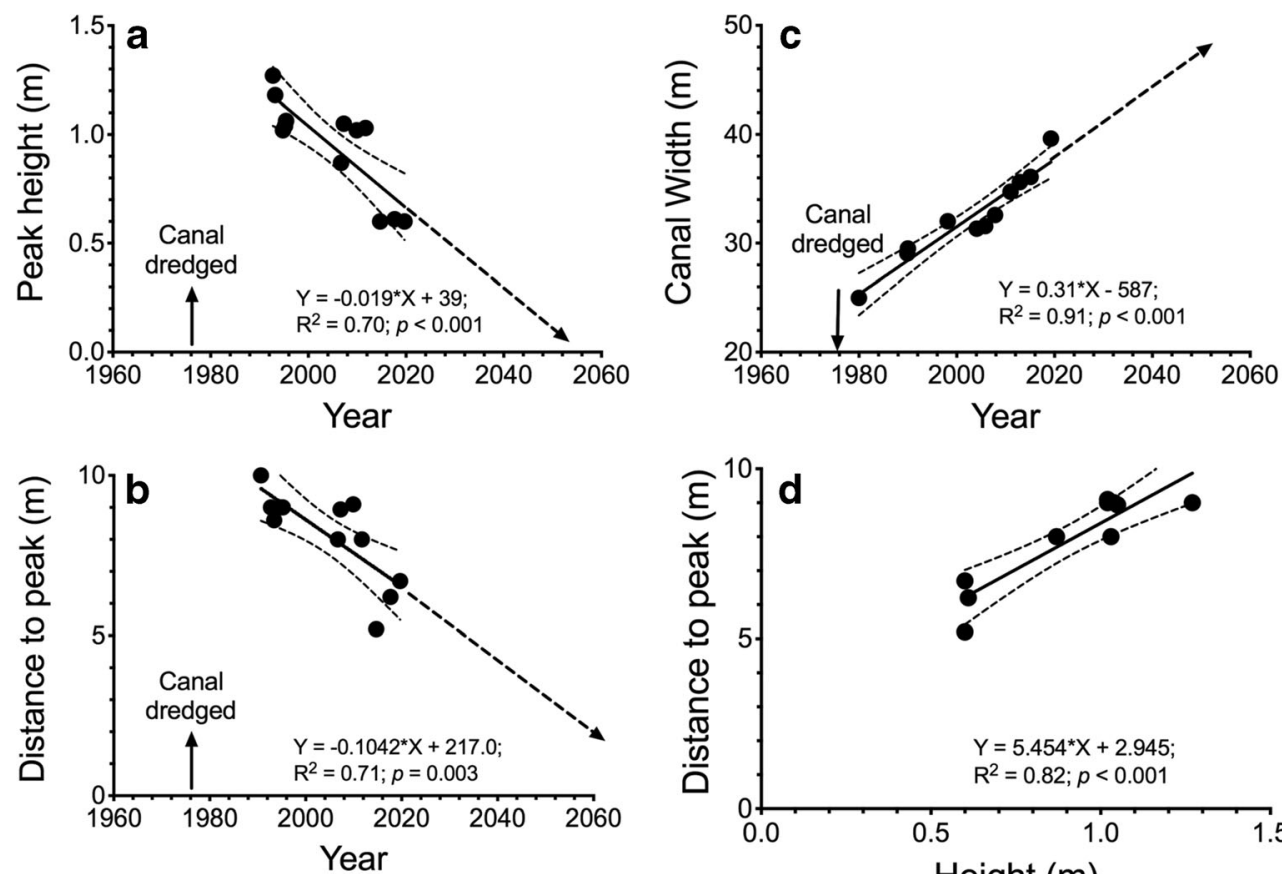

canal and natural salt marsh (Fig. 8). The line is a semi-log fit of all data where $Y=10^{(-0.05262 x+1.057)}\left(R^{2}=0.77\right.$, d.f. $\left.=25\right)$.

\section{Discussion}

\section{Spoil Bank Morphology}

If the current changes in spoil bank morphology since 1965 continue, then the estimated life time (post-construction) of spoil bank vegetation at the Cocodrie canal is 81 years, the emergent vegetative cover of any kind at the site will be gone after 88 years, the spoil bank width will be unrecognizable by 89 years, and the center of the former spoil bank will erode into the dredged canal within 118 years. The narrowing of the spoil bank width at the Cocodrie canal is within the same

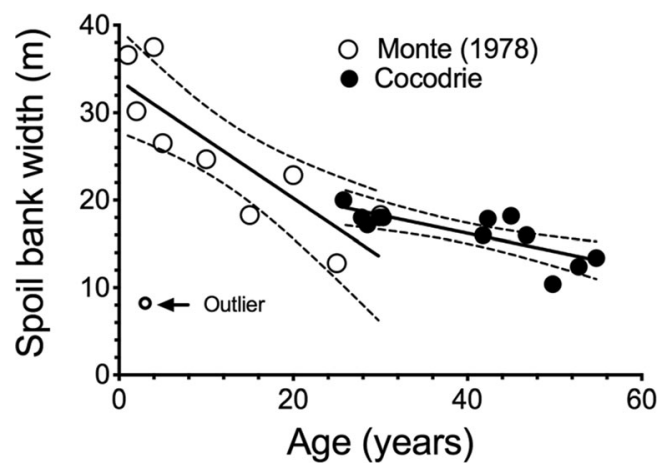

Fig. 4 The changes in spoil bank width from the Cocodrie canal edge to the marsh (Fig. 3) compared to the width of the nine differently aged canals in salt marshes of measured by Monte (1978). The dotted lines show a $95 \%$ confidence limit for each data set declining trajectory as for the canals examined by Monte (1978), which were not older than 25 years old. The erosion rates will be different in other areas depending on soil and vegetative characteristics. Quantifying the important influences on widening rates will need further investigation, but surely should include measurements of bulk density, vegetation, boat traffic and drainage network. At these decay rates, the inhibition of overland flow will be nil after a century (when they are at salt marsh level), and 20 years later for belowground flow (when the spoil bank is open water).

The height of the spoil bank at the Cocodrie canal is declining at $1.9 \mathrm{~cm}$ year $^{-1}$ relative to water level. This rate is 3.3 times the relative seal level rise rate from 1996 to 2016 in the Gulf of Mexico (5.6 cm year ${ }^{-1}$; Turner and Rabalais 2019), indicating that the spoil bank height is declining much more from compaction and erosion, than from eustatic sea level rise.

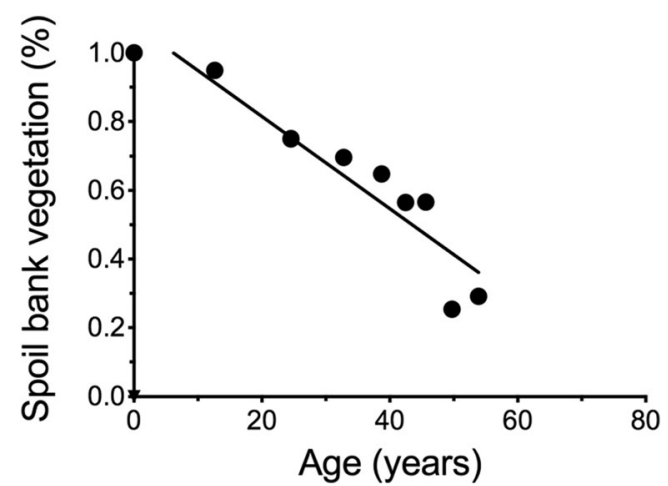

Fig. 5 The relative shrub and tree coverage on spoil banks for the spoil bank studied. A linear regression equation is fit to the data 


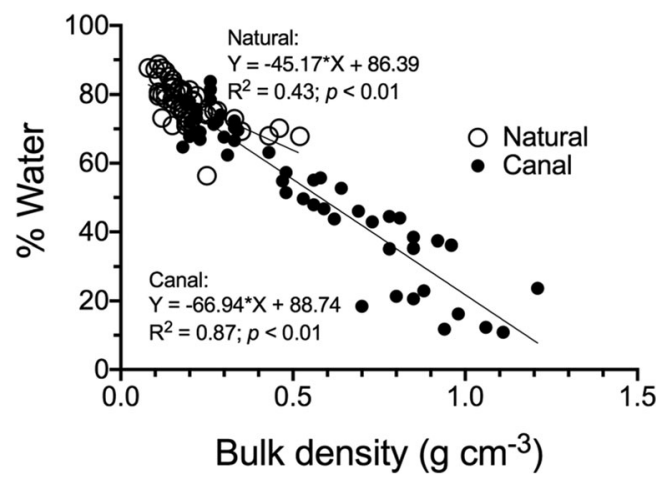

Fig. 6 The relationship between bulk density in the surface layer of the soil and the percent water content for soils collected at the dredged canal and the natural marsh
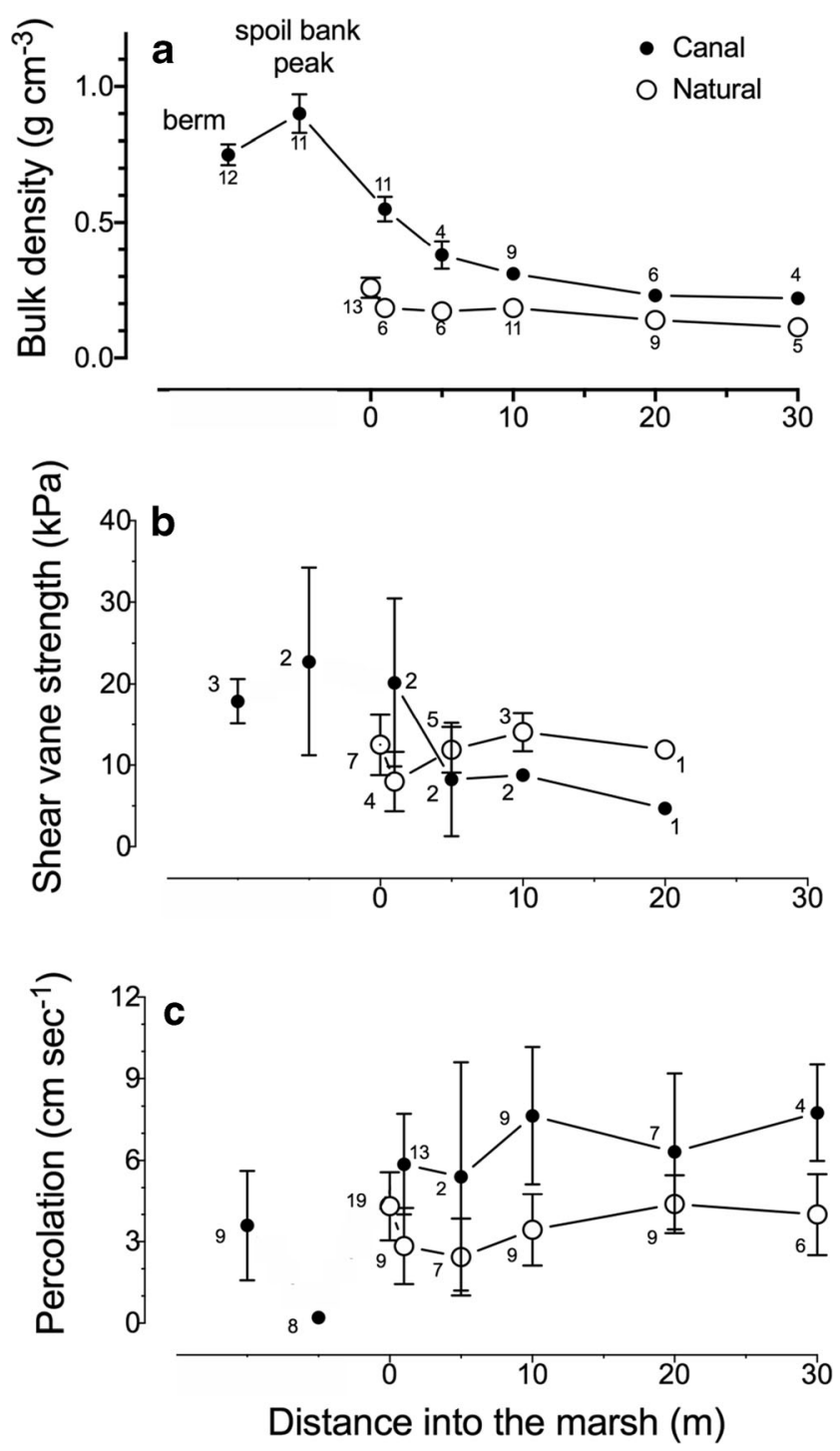

Fig. 7 The changes with distance into the marsh for: a bulk density, b Shear vane strength, and c percolation for the spoil bank and natural marsh. The distance is measured going away from the levee for the natural marsh (0) and distance away from the edge of the spoil bank on the marsh side and into the marsh. The numbers beside each data point are the sample size and the error bars are \pm 1 S.E

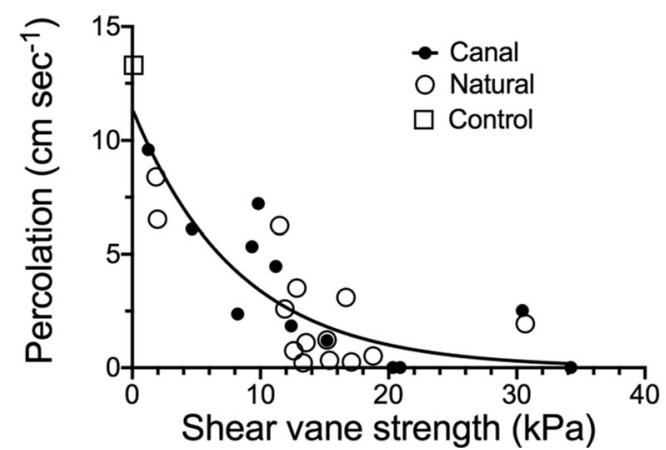

Fig. 8 The relationship between the shear vane strength $(\mathrm{kPa})$ in the 20 $40 \mathrm{~cm}$ deep layer and the relative percolation $\left(\mathrm{cm} \mathrm{s}^{-2}\right)$ at the canal and natural marsh

A brief summary of spoil bank morphology before dredging, within weeks after dredging, and then 1 and 30 years later is Fig. 9 (a) the original salt marsh has an organic layer overlying a mostly mineral soil that is parallel to the surface. Measurements in both of our salt marshes showed that the organic layer was nominally $1-1.5 \mathrm{~m}$ thick. (b) The canal was dredged completely through this marsh peat and another 2-3 $\mathrm{m}$ into the mineral layer, ending up ca. 3-5 $\mathrm{m}$ deep. The dredged material was placed on either side of the canal to form a continuous spoil bank 1-2 m parallel to the canal. (c) The canal widened slightly as material consolidates, and the spoil bank height declines as it sinks into the organic layer, compressing the organic layer, but the mineral layer remaining largely in place. Nichols (1959) made measurements of the compaction in a salt marsh having a $0.3-1 \mathrm{~m}$ thick organic layer. He observed that the compaction of the organic layer under the $2 \mathrm{~m}$ high spoil bank was $40 \%$ within 1 year. The exposed spoil mound narrows as the levee sinks. Slumping, erosion and spillage resulted in more dredged material accumulating on the canal sides and before vegetation cover develops. After 1 year the canal widens as it expands into the berm that then becomes narrower. (d) Ponds may form parallel to the canal on the salt marsh side where some of the eroding spoil bank spreads out over the salt marsh. The mineral layer beneath the spoil bank compacts under the weight of the spoil bank, but at a slower rate than the organic layer did above it. Eventually, within $40-120$ years, the trees and shrubs on the spoil bank whither, creeks cross through small openings and widen, the salt marsh becomes open water, and the spoil bank disappears.

\section{Soil Metrics}

The bulk density of the spoil bank studied at Cocodrie is $1.0 \mathrm{~g}$ $\mathrm{cm}^{-3}$ or higher and declines towards the salt marsh behind it where the soil strength becomes weaker and the percolation rate and soil bulk density are higher than in the natural salt marsh. The bulk density in the natural salt marsh was $58 \%$ of the bulk density in the marsh behind the spoil bank, which is 
Fig. 9 A schematic summary of spoil bank morphology before dredging, (a) within weeks after dredging (b), and then 1 year (c) and 30 years later $(\mathbf{d})$. Not shown: the spoil bank trees and shrubs on the spoil bank whither, creeks cross through small openings and widen, the marsh becomes open water, and the spoil bank disappears. The figure is not to scale a
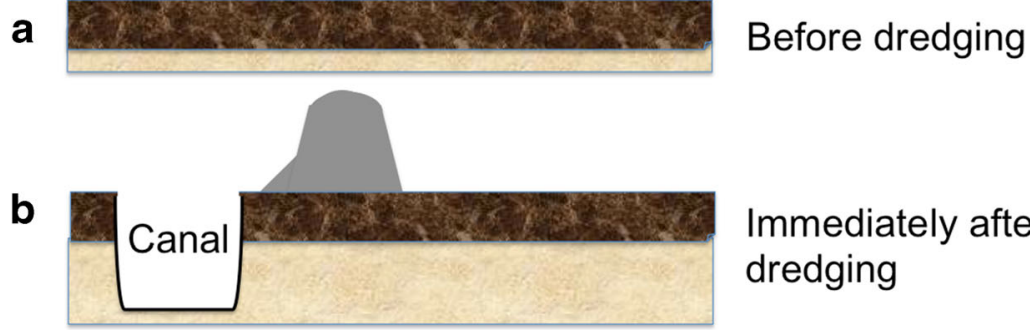

Immediately after dredging

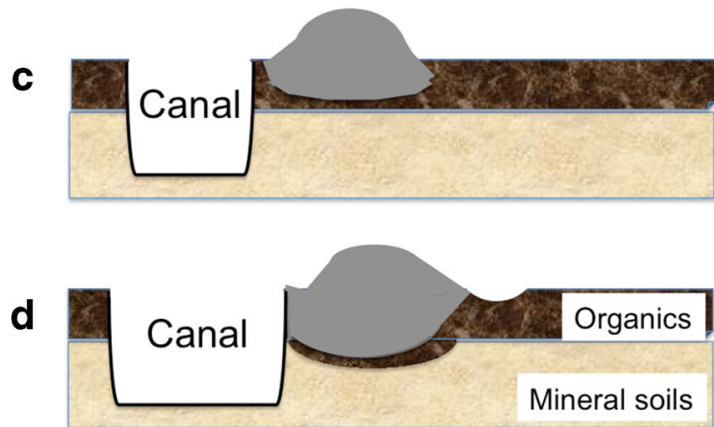

$1 \mathrm{y}$ after dredging

$30+y$ after dredging consistent with the measurements of Delaune et al. (1989) and Cahoon and Turner (1989) (Table 1). They used a combination of radioisotopic tracers and feldspar markers to measure the bulk density and accumulation of mineral matter behind canals relative to nearby reference salt marshes in Lafourche Parrish which adjoins Terrebonne Parish where our study occurred. Cahoon and Turner's feldspar marker (2 years) indicated that the bulk density and mineral accumulation at the natural sites were $78 \%$ and $44 \%$ of values at the canal site, respectively. Delaune et al. (1989) used ${ }^{210} \mathrm{~Pb}$ and ${ }^{137} \mathrm{Cs}$ isotopic methods to determine that the bulk density and mineral accumulation at the natural sites were $76 \%$ and $36 \%$ of values at the canal site, respectively.

The lower soil strength and higher hydraulic conductivity are consistent with the anticipated consequents arising from the fewer but longer flooding cycles, and less frequent but longer drying cycles behind spoil banks (Swenson and Turner 1987) which Nichols (1959) observed more than 60 years ago: "When water is over the marsh, the surface material is supersaturated and become very weak and almost fluid." The longer flooding reduces the amount of belowground biomass and increases the potential sedimentation of mineral matter (Stagg et al. 2019; Alldred et al. 2020); the longer drying cycles results in increased oxidation of the soil carbon which lowers the soil surface, increasing flooding duration and causing plant stress. This effect of subsidence is most significant in these coastal salt marshes because they occupy a narrow tidal range (McKee and Patrick 1988). The combination of longer flooding cycles, and less oxygen diffusion through flooded soils contributes to lower redox profiles, fewer roots and weaker roots (Pezeshki 1991; Hollis and Turner 2019; Alldred et al. 2020).

Table 1 Bulk density $\left(\mathrm{A} ; \mathrm{g} \mathrm{cm}^{-3}\right)$ and mineral accumulation $\left(\mathrm{B} ; \mathrm{g} \mathrm{m}^{2}\right.$ year $\left.{ }^{-1}\right)$ measurements at the natural and dredged salt marshes in this study and by others. (' $n$ ' is the number of sites)

\begin{tabular}{|c|c|c|c|c|}
\hline \multicolumn{5}{|c|}{ A. Bulk density $\left(\mathrm{g} \mathrm{cm}^{-3}\right)$} \\
\hline (1) & $(2)$ & (3) & $(3 / 2)$ & \\
\hline Soil Depth (cm) & Canal (n) & Natural (n) & Natural/Canal & Source \\
\hline 2 & $0.18(6)$ & $0.14(6)$ & $78 \%$ & Cahoon and Turner (1989) (Table 4; feldspar markers) \\
\hline 11 & $0.27(1)$ & $0.15(1)$ & $58 \%$ & This study (surface core) \\
\hline $50-100$ & $0.21(6)$ & $0.16(6)$ & $76 \%$ & Delaune et al. (1989), Table 2 (radioisotopes) \\
\hline \multicolumn{5}{|c|}{ B. Mineral accretion $\left(\mathrm{g} \mathrm{cm}^{-2}\right.$ year $\left.^{-1}\right)$} \\
\hline (1) & $(2)$ & (3) & $(3 / 2)$ & \\
\hline Soil Depth (cm) & Canal (n) & Natural (n) & Natural (n) & Source \\
\hline 2 & $0.18(6)$ & $0.08(6)$ & $44 \%$ & Cahoon and Turner (1989) (Table 4; feldspar markers) \\
\hline $50-100$ & $0.14(6)$ & $0.05(6)$ & $36 \%$ & Delaune et al. (1989) (Table 2; radioisotopes) \\
\hline
\end{tabular}


A major factor controlling the inverse relationship between shear vane strength and hydraulic connectivity between pore spaces (percolation) is root biomass. Roots are directly related to soil strength (Sasser et al. 2018) and the fine-scale sized roots fill the porewater space with soft tissue made up of a high percentage of water. The densely packed root mass in organic soils hold a lot of water compared to mineral soils, but water does not flow quickly between the air and water pore spaces outside of the roots.

\section{Environmental Variances Affecting Spoil Bank Influences}

Spoil banks are a linear feature built to recover, without regard to the surface soils, the pockets of oil and gas concentrations found thousands of $\mathrm{m}$ belowground. Their significance to marsh survival is dependent on a plethora of factors involved determining, for example, the amount and quality of belowground biomass, distance to the spoil bank, flooding, elevation of the salt marsh platform, degree of impoundment, sediment accumulation and time. These variables are heterogeneously distributed in the vertical and horizontal planes to be altered by spoil banks and canals of various lengths for reasons unrelated to salt marsh soil characteristics. It is not surprising, therefore, that: (1) there are often, but not always, transient ponds ( $<20 \mathrm{ha}$ ) within $500 \mathrm{~m}$ of canals that are more likely to remain as ponds than convert to salt marsh than further away from the canal, (2) open water is more likely to form, but not always form, within a complex of spoil banks than alongside a single spoil bank (Turner and Rao 1990), or that (3) land loss within 15 min quadrangle maps of the deltaic plain from the 1930 s to 1990 s is directly related to canal density and the intercept goes through zero (Turner and McClenachan 2018). These observations give support to deconstructing spoil bank for wetland restoration (Turner et al. 1994; Turner and McClenachan 2018).

Acknowledgments We thank Ollie Houck, Jim M. Lee, Charlie Milan, Gary Peterson and the hundreds of students who went on the field trips from 1990 to 2019 to observe, collect and dig into the spoil bank and salt marsh and to make inquiries with each other. The staff at the Louisiana Universities Marine Consortium at Cocodrie, LA, and the Sea Grant boat shop at Louisiana State University kept us afloat.

Open Access This article is licensed under a Creative Commons Attribution 4.0 International License, which permits use, sharing, adaptation, distribution and reproduction in any medium or format, as long as you give appropriate credit to the original author(s) and the source, provide a link to the Creative Commons licence, and indicate if changes were made. The images or other third party material in this article are included in the article's Creative Commons licence, unless indicated otherwise in a credit line to the material. If material is not included in the article's Creative Commons licence and your intended use is not permitted by statutory regulation or exceeds the permitted use, you will need to obtain permission directly from the copyright holder. To view a copy of this licence, visit http://creativecommons.org/licenses/by/4.0/.

\section{References}

Alldred M, Borrellis JJ, Hoellein T, Bruesewitz D, Zarnoch C (2020) Marsh plants enhance coastal marsh resilience by changing sediment oxygen and sulfide concentrations in an urban, eutrophic estuary. Estuaries and Coasts 43:801-813

Allen JRL, Fulford MG (1990) Romano-British wetland reclamations at Longeney, Gloucestershire, and evidence for the early settlement of the inner Severn estuary. The Antiquaries Journal 70:288-326. https://doi.org/10.1017/S0003581500070815

Ash EH (2017) The draining of the fens: projectors, popular politics, and state building in early modern England. Johns Hopkins Studies in the History of Technology, Baltimore

Bourn WS, Cottam C (1950) Some biological effects of ditching tidewater marshes. U.S. Fish Wildlife Service Research Report 19. U.S. Department of Interior, Washington, DC

Butzer KW (2002) French wetland agriculture in Atlantic Canada and its European roots: different avenues to historical diffusion. Annals American Geographers 92:451-470

Cahoon DR, Turner RE (1989) Accretion and canal impacts in a rapidly subsiding wetland. II. Feldspar marker horizon technique. Estuaries $12: 260-268$

Couvillion BR, Beck H, Schoolmaster D, Fischer M (2017) Land area change in coastal Louisiana (1932 to 2016). Pamphlet to accompany U.S. Geological Survey Scientific Investigations Map 3381, p 16.https://doi.org/10.3133/sim3381

Daigh FC, Stearns LA (1939) Effect of ditching for mosquito control on the $\mathrm{pH}$ of marsh soils. Proceedings of the New Jersey Mosquito Extermination Association 26:39-43

Daigh FC, MacCreary D, Stearns LA (1938) Factors affecting the vegetative cover of Delaware marshes. Proceedings of the New Jersey Mosquito Extermination Association 25:209-216

Delaune RD, Whitcomp JH, Patrick WH Jr, Pezeshki SR (1989) Accretion and canal impacts. I. ${ }^{137} \mathrm{Cs}$ and ${ }^{210} \mathrm{~Pb}$ techniques. Estuaries 12:247-259

Eggelsmann R (1976) Peat consumption under influence of climate, soil condition, and utilization. Proceedings International Peat Congress, vol. 1. International Peat Society, Poznan, Poland pp. 233-247

Hollis LO, Turner RE (2019) The tensile root strength of Spartina patens: response to flood duration and nutrient addition. Plos One. Submitted 12 Oct.

Jacobsen T, Adams RM (1958) Salt and silt in ancient Mesopotamian agriculture. Science 128:1251-1258

Mann CC (2008) Ancient earthmovers of the Amazon. Science 142: $1148-1152$

Mckee KL, Patrick WH Jr (1988) The relationship of smooth cordgrass (Spartina alterniflora) to tidal datums: a review. Estuaries 11:143151

Monte JA (1978) The impact of petroleum dredging on Louisiana's coastal landscape: a plant biogeographical analysis and resource assessment of spoil. Ph.D. Dissertation. Louisiana State University, Baton Rouge

Nichols LG (1959) Rockefeller refuge Levee study. Louisiana Wildlife Fisheries Commission Refuge Division Technical report, Baton Rouge

Niklas KJ, Spatz HC (2012) Plant physics. University of Chicago Press, Chicago

Ohimain EI (2003) Environmental impacts of oil mining activities in the Niger Delta mangrove ecosystem. 8th International Congress on Mine Water \& the Environment, Johannesburg, pp 503-517

Peterson GW, Turner RE (1994) The value of salt marsh edge vs interior as a habitat for fish and decapod crustacean in a Louisiana tidal marsh. Estuaries 17:246-273

Pezeshki SR (1991) Wetland plant responses to soil flooding. Environmental and Experimental Botany 46:299-312 
Rippon S (2000) The transformation of coastal wetlands: exploitation and management of marshlands landscapes in North West Europe during the Roman and medieval periods. Oxford University Press, Oxford. isbn:0-19-726229-5

Sasser CE, Evers-Hebert E, Holm GO Jr, Milan B, Sasser JB, Peterson F, DeLaune RD (2018) Relationships of marsh soil strength to belowground vegetation biomass in Louisiana coastal marshes. Wetlands 38:401-409

Stagg CL, Osland MJ, Moon JA, Hall CT, Feher LC, Jones WR, Couvillion BR, Hartley SB, Vervaeke WC (2019) Quantifying hydrologic controls on local- and landscape-scale indicators of coastal wetland loss. Annals of Botany 125:365-376

Stearns LA, MacCreary D, Daigh FC (1940) Effect of ditching for mosquito control on the muskrat population of a Delaware tidewater marsh. University of Delaware Agricultural Experiment Station Bulletin 255:1-55

Swenson EM, Turner RE (1987) Spoil banks: effects on a coastal marsh water level regime. Estuarine, Coastal and Shelf Science 24:599 609

Turner RE (2004) Coastal wetland subsidence arising from local hydrologic manipulations. Estuaries 27:265-273

Turner RE, McClenachan G (2018) Reversing wetland death from 35,000 cuts: opportunities to restore Louisiana's dredged canals. PLoS One 13(12):e0207717. https://doi.org/10.1371/journal.pone.0207717
Turner RE, Rabalais NN (2019) The gulf of Mexico. Chapter 18. In: Shepard C (ed) World seas: an environmental evaluation, volume I: Europe, the Americas and West Africa. Elsevier, London, pp 445464

Turner RE, Rao YS (1990) Relationships between wetland fragmentation and recent hydrologic changes in a deltaic coast. Estuaries 13:272281

Turner RE, Swenson EM, Lee JM (1994) A rationale for coastal wetland restoration through spoil bank management in Louisiana, USA. Environmental Management 18(2):271-282

Turner RE, McClenachan G, Tweel AW (2016) Islands in the oil: quantifying salt marsh shoreline erosion after the Deepwater Horizon oiling. Marine Pollution Bulletin 110:316-323. https://doi.org/10. 1016/j.marpolbul.2016.06.046

Turner RE, Swarzenski C, Bodker JE (2020) Fresh marsh soil strength losses with small increases in $\mathrm{N}$ and $\mathrm{P}$ loading. Wetlands online. https://doi.org/10.1007/s13157-020-01265-w

Publisher's Note Springer Nature remains neutral with regard to jurisdictional claims in published maps and institutional affiliations. 